\title{
MICORRHIZAL BIOTECHNOLOGY AS AN ALTERNATIVE TO POTENTIALIZE THE STRAWBERRY QUALITY
}

\author{
BIOTECNOLOGIA MICORRÍZICA COMO ALTERNATIVA PARA POTENCIALIZAR A \\ QUALIDADE DO MORANGUEIRO
}

\author{
Rosiani Castoldi da COSTA ${ }^{1}$; Gregori Caglioni DURANTE ${ }^{2}$; Nicolas dos Santos TRENTIN ${ }^{2}$; \\ José Luís Trevizan CHIOMENTO' ${ }^{1}$; Fabiola Stockmans DE NARDI ${ }^{1}$; \\ Alexandre Augusto NIENOW ${ }^{1}$; Eunice Oliveira CALVETE ${ }^{1}$ \\ 1. Programa de Pós-Graduação em Agronomia - PPGAgro, da Faculdade de Agronomia e Medicina Veterinária -FAMV, Universidade \\ de Passo Fundo - UPF, Passo Fundo, RS, Brasil. rosianicastoldi@yahoo.com.br; 2. Curso de Agronomia da FAMV da UPF, Passo \\ Fundo, RS, Brasil.
}

\begin{abstract}
The need to develop and use biotechnology tools to improve management and nutritional techniques in strawberry cultivation are increasing. Based on this, the objective of this study was to test if the mycorrhizal inoculation changes the agronomic and qualitative performance of strawberry fruits. The strawberry daughters plants used were of the cultivar Camarosa. The study was carried out in an agricultural greenhouse, Horticulture Sector of the Faculty of Agronomy and Veterinary Medicine (FAMV) of UPF, in the city of Passo Fundo, Rio Grande do Sul (RS), Brazil. The experiment was developed and maintained from June to December 2015. The treatments consisted of five inoculum: T1 = no inoculum (control); T2 = Acaulospora morrowiae; T3 = Rhizophagus clarus; T4 = mycorrhizal community; T5 = Claroideoglomus etunicatum. The experimental design was a randomized block with four replicates. Each plot consisted of a bag containing 6 plants spaced $0.15 \mathrm{mx} 0.15 \mathrm{~m}$. In the pits of the plants, it was applied, with the aid of syringe and water, about 70 infective propagules of the tested inocula. During the conduction of the experiment the temperature and photosynthetically active radiation (PAR) were monitored in the culture environment. It was evaluated the agronomic and qualitative performance of the fruits and the percentage of mycorrhizal colonization of the plants roots. The data were submitted to analysis of variance and the differences between means were compared by the Tukey test at 5\% of probability error. The cultivar Camarosa produced more fruits in October. In September, the month before the one with the best agronomic performance, the mean temperature was $17.7^{\circ} \mathrm{C}$. The mean PAR recorded in the growing environment was low in relation to crop requirements, throughout the growing period. Fruits produced by plants inoculated with $A$. morrowiae presented higher values of TSS/TTA ratio in September and October. The percentage of mycorrhizal colonization varied from $26.2 \%$ for $A$. morrowiae to $46.2 \%$ for $R$. clarus. The inoculation of arbuscular mycorrhizal fungi does not alter the production of strawberry fruits. However, when the plants are inoculated with A. morrowiae there is an improvement in the fruit flavor.
\end{abstract}

KEYWORDS: Fragaria X ananassa Duch. Arbuscular mycorrhizal fungi. Total soluble solids. Titratable total acidity.

\section{INTRODUCTION}

The strawberry (Fragaria X ananassa Duch.), among the red fruits, is the most productive and economical expression, being cultivated in Europe, Asia, North and South America (TORUN et al., 2014). It is appreciated by its juicy texture and nutritive value. In Brazil, among the small fruits, the strawberry is the main cultivated species, with an approximate production of 150 thousand tons, in a planted area corresponding to 4.2 thousand ha (FAGHERAZZI et al., 2017).

Although the strawberry conventional cropping system (soil planting) is still the most used (COSTA et al., 2014) among producing countries, there is a growing migration to substrate cultivation. However, this system presents drawbacks, such as the high use of pesticides and fertilizers, mainly in relation to phosphorus $(\mathrm{P})$, where criteria and technical recommendations are not considered (PASZT et al., 2015).

In this way, there is a need to develop and use biotechnology tools to improve water use efficiency (DEPARDIEU et al., 2016) and to reduce the use of chemical fertilizers in fertigation (HARTZ; HOCHMUTH, 1996), which, in addition to having a high cost, have negative consequences for the environment, such as soil contamination, water (eutrophication by excess nutrients) and extraction of nonrenewable resources, such as $\mathrm{P}$ 
sources, which are limited (ELSER, 2012). One of the alternatives to make the strawberry production system more sustainable, maintaining and/or improving the yield and the qualitative potential of the fruits, is the use of arbuscular mycorrhizal fungi (AMF).

The AMF, representative of the phylum Glomeromycota, are obligate biotrophic microorganisms, which perform mutual symbiotic associations with $80 \%$ of the vascular plants, altering the morphology and physiology of the roots (AHANGER et al., 2014). They perform various ecological functions in exchange for host photosynthetic carbon (WILLIS; RODRIGUES; HARRIS, 2013). The benefit to the plant stems is the increase of the area of mycorrhizal roots exploration by means of hyphae network (GUTJAHR, 2014). The process of nutrient exchange between plant and fungus occurs in the arbuscules and depends on environmental and biological variables (MORCILLO et al., 2016).

The AMF have the potential to greatly improve the rhizospheric soil characteristics, improving plant growth and development (AHANGER et al., 2014; NAVARRO; PEREZTORNERO; MORTE, 2014) by means of increased water and nutrient uptake (GUTJAHR, 2014; GÓMEZ-BELLOT et al., 2015). The symbiosis between AMF and strawberry plants benefits yield (MARTINEZ; WEILAND; PALENCIA, 2013) and fruit quality (CECATTO et al., 2016; CHIOMENTO et al., 2019). The use of AMF can reduce the use of phosphate fertilizers in vegetables (ELBON; WHALEN, 2015), as is the case with strawberries. However, the studies that evaluate the maintenance and/or improvement in fruit production and quality of this species are still incipient. Thus, the hypothesis of the study is that, in addition to the AMF potentiate the absorption mainly of phosphorus present in the materials used as substrate, already described in the literature (SHARMA; ADHOLEYA, 2004), production gains and fruit quality can be visualized.

This study has relevance since this fruit is marketed worldwide. Therefore the objective of the study was to test if the mycorrhizal inoculation changes the agronomic and qualitative performance of strawberry fruits.

\section{MATERIAL AND METHODS}

\section{Plant material and experiment site}

The strawberry daughters plants used was from the Camarosa cultivar, obtained from in vitro cultivation (micropropagation) carried out at the Plant Biotechnology Laboratory at the University of Passo Fundo (UPF). After micropropagation, they were planted in polyethylene trays of 72 cells, filled with sterilized sand and acclimatized in an agricultural greenhouse for one month.

The study was carried out in an agricultural greenhouse of $430 \mathrm{~m}^{2}$, with a semicircular roof, installed in the northwest-southeast direction, located in the Horticulture Sector of the Faculty of Agronomy and Veterinary Medicine (FAMV) of the UPF, in the municipality of Passo Fundo (28 $15^{\prime} 46^{\prime \prime}$ S; 52 24'24" W), Rio Grande do Sul (RS), Brazil. The structure was made of galvanized steel and covered with low density polyethylene (LDPE) film, with anti-glare additive and with a thickness of 150 microns. The experiment was developed and maintained from June to December 2015.

\section{Treatments and experimental design}

The treatments consisted of five inoculum: $\mathrm{T} 1=$ no inoculum (control); $\mathrm{T} 2=$ Acaulospora morrowiae Spain \& Schenck; T3 = Rhizophagus clarus (T.H. Nicolson \& N.C. Schenck) C. Walker \& A. Schüßler; T4 = mycorrhizal community; T5 = Claroideoglomus etunicatum (W.N. Becker \& Gerd.) C. Walker \& A. Schüßler. The experimental design was a randomized block with four replicates. Each plot consisted of a bag containing 6 plants spaced $0.15 \mathrm{~m} \times 0.15 \mathrm{~m}$.

\section{Procedures}

After acclimatization, the strawberry daughters plants were transplanted in bags $0.5 \mathrm{~m}$ long by $0.3 \mathrm{~m}$ wide, filled with Mec Plant Horta $2^{\circledR}$ substrate, arranged horizontally on the ground according to the sketch of the experiment (Figure 1).

The isolates of AMF (A. morrowiae, $R$. clarus and $C$. etunicatum) were obtained from the International Collection of Glomeromycota Cultures (CICG), located at the Regional University of Blumenau (FURB), Santa Catarina (SC), Brazil. The mycorrhizal community was obtained from soil collected at the strawberry cultivation site in the UPF, Horticulture Sector. In the first year of cultivation (2014), the plants served as matrices for the production of new strawberry daughters plants. After this period, they were subjected to drastic cleaning (removal of all leaves) to start the present study. 


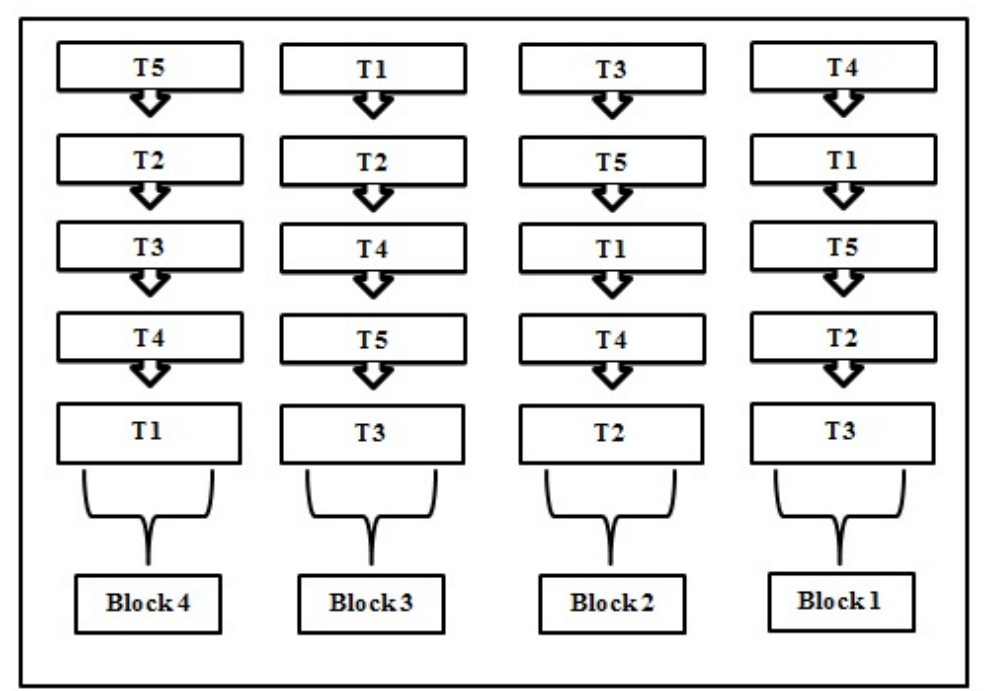

Figure 1. Configuration of the experimental study: $\mathrm{T} 1=$ no inoculum $($ control); $\mathrm{T} 2=$ A. morrowiae; $\mathrm{T} 3=R$. clarus; $\mathrm{T} 4=$ mycorrhizal community; $\mathrm{T} 5=$ C. etunicatum .

Samples were collected of the substrate for chemical analysis (Table 1). Throughout the crop evaluation period, irrigation was distributed through a drip system at the spacing of $0.3 \times 0.3 \mathrm{~m}$.
According to the substrate chemical analysis, it was not necessary to administer fertigation during the growing period.

Table 1. Substrate chemical analysis.

\begin{tabular}{|c|c|c|c|c|c|c|c|c|c|c|c|c|}
\hline \multirow{2}{*}{$\begin{array}{l}\text { Clay } \\
(\%)\end{array}$} & \multirow{2}{*}{$\begin{array}{l}\mathrm{pH}^{1} \\
\mathrm{H}_{2} \mathrm{O}\end{array}$} & \multirow{2}{*}{$\begin{array}{l}\text { SMP } \\
\text { index }\end{array}$} & $\mathrm{P} \quad \mathrm{K}$ & \multirow{2}{*}{$\begin{array}{l}\text { OM } \\
(\%)\end{array}$} & $\mathrm{A}$ & $\mathrm{Ca}$ & $\mathrm{Mg}$ & $\mathrm{H}+\mathrm{Al}$ & CEC & \multicolumn{3}{|c|}{ Saturation } \\
\hline & & & $\mathrm{mg} \mathrm{dm}{ }^{-3}$ & & \multicolumn{5}{|c|}{$\mathrm{cmol}_{\mathrm{c}} \mathrm{dm}^{-3}$} & $\begin{array}{l}\text { Base } \\
\%\end{array}$ & $\mathrm{Al}$ & K \\
\hline 32.4 & 6.0 & 6.2 & $>51 \quad 493$ & $>6.7$ & 0 & 10.4 & 4.9 & 3.5 & 20.0 & 83 & 0 & 6.3 \\
\hline
\end{tabular}

${ }^{1} \mathrm{pH} \mathrm{H}_{2} \mathrm{O}$ : hydrogen potential in water; SMP index: Shoemaker-Mac'Lean-Pratt index; P: phosphorus; K: potassium; OM: organic matter; Al: aluminum; Ca: calcium; $\mathrm{Mg}$ : magnesium; $\mathrm{H}+\mathrm{Al}$ : potential acidity; $\mathrm{CEC}$ : cation exchange capacity.

\section{Mycorrhizal inoculation}

The inoculation of the AMF was carried out shortly after the cleaning of the plants. Using a syringe, they were applied in the pit, approximately 70 infective propagules of each isolate and mycorrhizal community that were diluted in $10 \mathrm{ml}$ of water. The application of the inocula occurred according to the distribution of the treatments.

\section{Microclimate}

During the conduction of the experiment the temperature and photosynthetically active radiation (PAR) were monitored in the culture environment. For this, a meteorological mini-station was used, located inside the agricultural greenhouse, from which the data were extracted.

\section{Agronomic performance}

In the fruit yield, the number (total and commercial) and weight (total and commercial) of fruits per plant were evaluated weekly. Commercial fruits were those weighing more than $6 \mathrm{~g}$ and devoid of injuries.

\section{Qualitative performance}

The chemical quality of the fruits was based on the evaluation of the total soluble solids (TSS) content, expressed in brix, and the titratable total acidity (TTA), expressed in \% of citric acid. The TSS content was determined using an analog refractometer, while the TTA was performed according to the standards of the Adolfo Lutz Institute (IAL, 2008). To evaluate the taste of the fruits, the TTS/TTA ratio was determined.

\section{Mycorrhizal colonization}

To determine the percentage of mycorrhizal colonization of the plants' roots, at the end of the experiment, $1 \mathrm{~g}$ of root per plant was collected. They were washed in running water, then clarified in $10 \% \mathrm{KOH}$, acidified with $1 \% \mathrm{HCl}$, colored with $0.05 \%$ tripan blue and preserved in lactic acid (PHILLIPS; HAYMAN, 1970). The percentage of segments colonized by mycorrhizae was determined according to Trouvelot, Kouch and GianinazziPearson (1986) by the formula: \% MC $=(($ total number of fragments with mycorrhized roots)/(total number of fragments)) $\mathrm{x} 100$. The segments that 
presented hyphae (external and internal), vesicles or arbuscules were considered colonized.

\section{Data analysis}

For fruit yield, the harvests were grouped according to five harvesting periods (months) constituting a bifatorial (5 inocula x 5 months of harvest). For fruit quality, the quantification of the TSS/TTA ratio also corresponded to a bifatorial (5 inocula $\mathrm{x} 4$ months of harvest).

All data, including the percentage of mycorrhizal colonization of the plants' roots, were submitted to analysis of variance (Anova) and the differences between means were compared by the Tukey test at $5 \%$ of probability error.

\section{RESULTS}

The cultivar Camarosa produced the largest number of fruits in October, with a total and commercial number of fruits of $40.1 \mathrm{~g} \mathrm{plant}^{-1}$ and $29.1 \mathrm{~g}$ plant $^{-1}$, respectively (Figure $2 \mathrm{~A}$ ). Considering strawberry production, it was also in October that the highest yield was obtained, with a total and commercial weight of fruits of $402.1 \mathrm{~g} \mathrm{plant}^{-1}$ and 349.4 g plant $^{-1}$, respectively (Figure $2 \mathrm{~B}$ ).
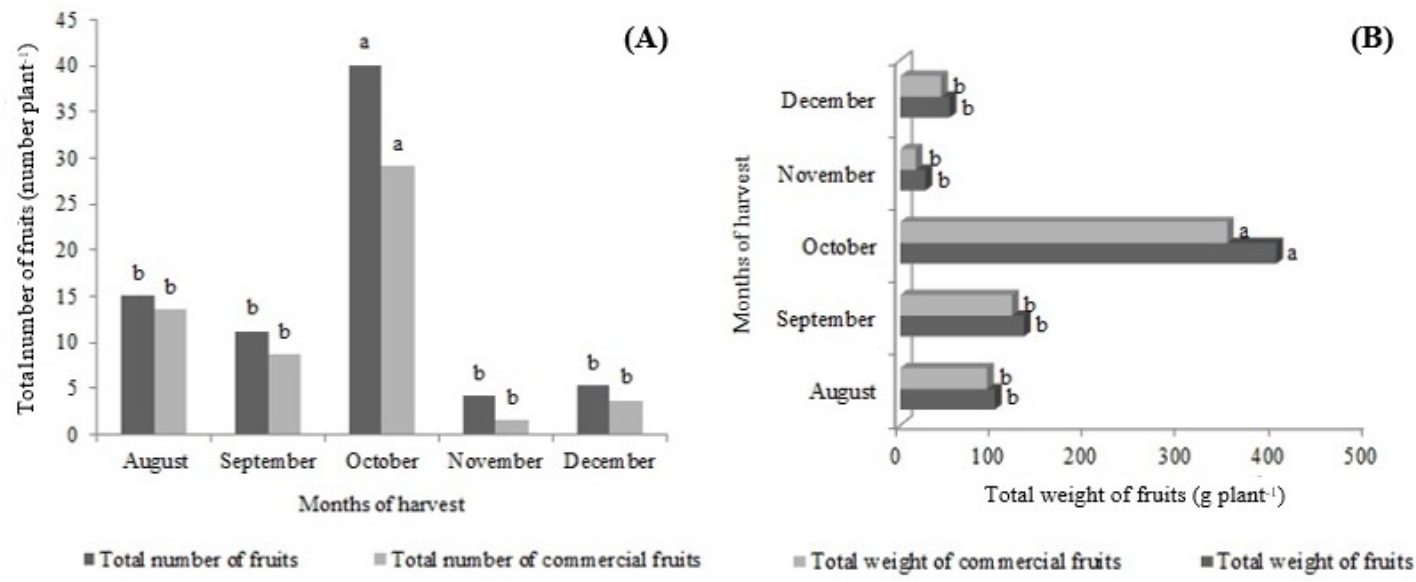

Figure 2. Total and commercial number of fruits, in number plant ${ }^{-1}(\mathrm{~A})$; total and commercial weight of fruits, in $g_{\text {plant }}{ }^{-1}$ (B). Means followed by the same lowercase letter do not differ by the Tukey test at $5 \%$ of error probability $(p \leq 0.05, n=4)$.

In September, the month preceding the one with the best agronomic performance, the average temperature was $17.7^{\circ} \mathrm{C}$ (Figure 3). From this period, the average temperatures inside the environment were higher. The average PAR recorded in the growing environment (Figure 3) was considered low in relation to strawberry cultivation requirement. In October, the month of the greatest fruit production, the average PAR was higher (268.2 $\mu \mathrm{mol} \mathrm{m} \mathrm{s}^{-1}$ ) in comparison to the previous months.

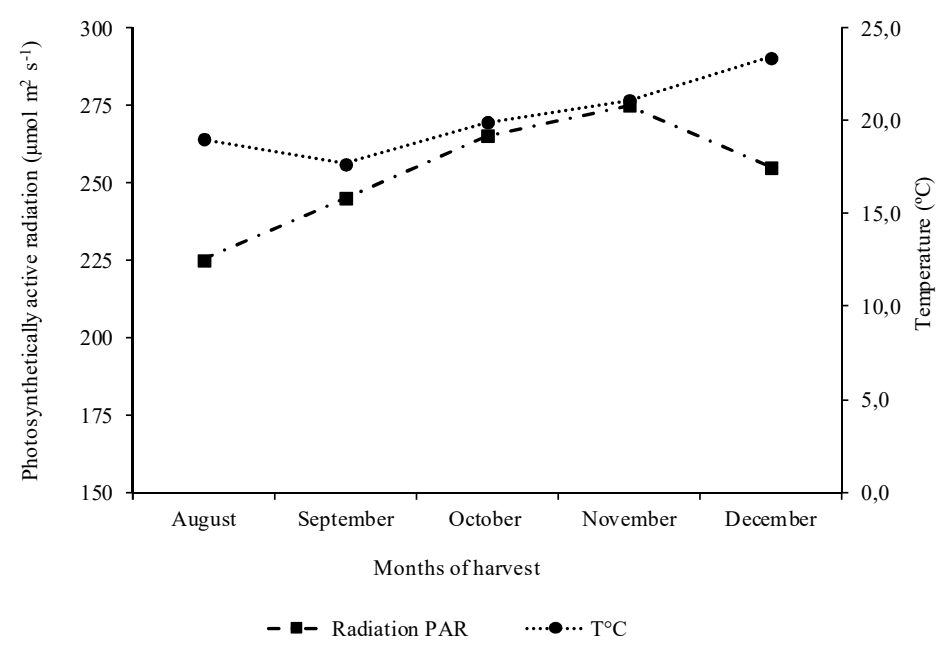

Figure 3. Averages of PAR and temperature recorded in the environment during the harvest period. 
Considering the quality of the fruits harvested, there was interaction between inocula and harvest months for TSS/TTA ratio (Table 2). In the interaction, considering the months within each inoculum, October was highlighted with higher value for this relation (10.6) for plants colonized by A. morrowiae. Considering the inocula within each month, fruits produced by plants inoculated with $A$. morrowiae showed higher values of the TSS/TTA ratio in September and October (11.6 and 10.6, respectively) and September for mycorrhizal community and C. etunicatum (9.2 and 10.6, respectively).

Table 2. TSS/TTA ratio of the Camarosa cultivar submitted to different AMF treatments.

\begin{tabular}{|c|c|c|c|c|c|}
\hline \multirow{2}{*}{ Treatments } & \multicolumn{5}{|c|}{ Harvest months } \\
\hline & September & Octo & & November & December \\
\hline Control & 10.3 aA & 8.4 & $\mathrm{bA}$ & 7.9 aA & $6.5 \mathrm{aA}$ \\
\hline A. morroviae & $11.6 \mathrm{aA}$ & 10.6 & $\mathrm{aA}$ & $6.8 \mathrm{aB}$ & $6.5 \mathrm{aB}$ \\
\hline R. clarus & $11.4 \mathrm{aA}$ & 8.5 & $\mathrm{bA}$ & 5.9 aA & $5.5 \mathrm{aA}$ \\
\hline Mycorrhizal community & $9.2 \quad \mathrm{aA}$ & 6.0 & $\mathrm{cB}$ & $6.0 \mathrm{aB}$ & $5.2 \mathrm{aB}$ \\
\hline C. etunicatum & $10.6 \mathrm{aA}$ & 8.7 & $\mathrm{dAB}$ & $5.2 \mathrm{aB}$ & $5.3 \mathrm{aB}$ \\
\hline Mean & 10.6 & 8.5 & & 6.3 & 5.8 \\
\hline Coefficient of variation $(\%)$ & 20.6 & 4.4 & & 12.3 & 17.0 \\
\hline
\end{tabular}

Means followed by the same lowercase letter in the column and upper case in the line do not differ by the Tukey test at $5 \%$ error probability $(\mathrm{p} \leq 0.05, \mathrm{n}=4)$.

Mycorrhizal colonization (MC) of the strawberry roots did not differ between treatments (Table 3). At the end of cultivation the plants' roots inoculated with A. morrowiae presented only $26.2 \%$ of colonization, while $R$. clarus, $46.2 \%$.

Table 3. Anova referring to mycorrhizal colonization (MC) of strawberry roots, inoculated with AMF.

\begin{tabular}{lll}
\hline \multirow{2}{*}{ Causes of variation } & Degrees of freedom & Mean square \\
\cline { 3 - 3 } & 3 & MC $(\%)$ \\
\hline Blocks & 4 & $393.64^{\text {ns }}$ \\
Inocula & 12 & $212.50^{\text {ns }}$ \\
Error & 19 & \\
\hline Total &
\end{tabular}

\section{DISCUSSION}

The inoculation of AMF did not alter the agronomic performance of strawberry. However, it provided an improvement in the quality of the fruits of the Camarosa cultivar (Table 2).

In the month (September) that preceded the highest productive expression (October), the average temperature $\left(17.7{ }^{\circ} \mathrm{C}\right)$ recorded in the environment (Figure 3) was considered optimal for floral induction $\left(18^{\circ} \mathrm{C}\right)$ and fruit production $\left(24^{\circ} \mathrm{C}\right)$ (OPSTAD et al., 2011; SØNSTEBY; HEIDE, 2008; WANG; CAMP, 2000), which was confirmed by the best results obtained in October. From this period, the average temperatures inside the environment were higher, mainly affecting the induction and differentiation of vegetative buds in floriferous, compromising the agronomic performance of the plants. It is worth mentioning that the sensitivity of plants to high temperatures varies with their size and age. Allied to temperature, the PAR is recorded in the growing environment (Figure 3). Temperature and solar radiation are primary factors in the control of growth and development of strawberry plants (PALENCIA et al., 2013).

In October, the PAR was higher (268.2 $\mu \mathrm{mol} \mathrm{m} \mathrm{m}^{2}$ ) compared to the months preceding that period, but still below the range considered ideal for floral induction and, consequently, fruit production (400 to $450 \mu \mathrm{mol} \mathrm{m} \mathrm{m}^{2}$ ). The intensity and quality of light are important for strawberry production. The production of flowers and fruits can be improved with light intensity between 400 and $450 \mu \mathrm{mol} \mathrm{m}^{2} \mathrm{~s}^{-1}$ of PAR (KIRSCHBAUM, 1998). The quality and intensity of light is of particular importance for the different strawberry cultivars, being the necessary stimulus for the floral evocation, induction and differentiation of the meristematic regions, determining the activation of specific genes (SOC1 and LFY) (HEIDE; STAVANG; SØNSTEBY, 2013; JUNG et al., 2012) responsible by the 
formation of floral whorls (CORBESIER; COUPLAND, 2005; TAIZ et al., 2017), also helping, in fruit maturation, which is the main index for classification and harvesting (XU; ZHANG, 2007). It is inferred that the quality of the light, together with the elevation of the temperature in the environment from October may have negatively affected the flowering process, thus compromising the formation and development of the fruits.

Considering the qualitative performance of the strawberry fruits of the cultivar studied, the inoculation with AMF showed interference in the attribute used to determine the fruit flavor (TSS/TTA ratio). Ideal values of this relationship which determines the taste are found when the titratable acidity quantification is between 0.5 to $1.87 \%$ and the total soluble solids content ( ${ }^{\circ}$ brix) between 5 and 12 (PERKINS-VEAZIE; COLLIN, 1995). With these values, the fruits present good palatability and acceptance.

In this study, it was understood that the inoculation in the strawberry plants with AMF configured plant stress by the low percentage of mycorrhizal colonization found in the roots, regardless of the inoculum, diverting the carbon that would be destined to the formation of biomass for the production of compounds of the secondary metabolism (such as anthocyanins and polyphenols) in an attempt, at first, to defend against the fungus. Depending on the environmental conditions such as moderate temperatures around $20^{\circ} \mathrm{C}$, sugar is released by the degradation of these compounds, determining an increase in sugar content in fruits (FRANCIS, 1989).

The accumulation of sugar in the fruits is higher when the fruit develops at lower temperatures (KIMURA, 2008) confirming higher TSS/TTA ratios in the month of October, since the month before that time was the fruit development period. The higher the TSS/TTA ratio, the more acceptable the consumer is and the tastier the fruit.

The low mycorrhizal colonization $(26.2 \%$

for A. morrowiae and $46.2 \%$ for $R$. clarus) presented by the plants' roots may also be related to the temperatures recorded in the environment (Figure 3). The ideal temperature range is variable with the adaptation of the fungal species. In general, at temperatures around $30^{\circ} \mathrm{C}$ there is an increase in the mycorrhizal colonization and sporulation by AMF (SILVEIRA, 1998), which would potentiate root colonization. In the present study mean temperatures throughout the growing season were below this range.

The $\mathrm{pH}$ of the substrate used to fix the plants' roots is also one of the factors that influence the plant/fungus association. Low $\mathrm{pH}$ values favor species of the genus Acaulospora whereas species of the genus Claroideoglomus prefer $\mathrm{pH}$ close to neutrality (TRUFEN, 1990). This fact was confirmed in our study because plants inoculated with the Acaulospora isolate had a lower colonization rate $(26.2 \%)$ while the isolate Claroideoglomus had a higher value $(46.2 \%)$ because the $\mathrm{pH}$ of the substrate used was 6.0 (Table $1)$.

The phosphorus content is another factor that may have negatively affected the mycorrhizal colonization of the roots of the inoculated plants. For the substrate used presented $>51 \mathrm{mg} \mathrm{dm}^{-3}$ of phosphorus (Table 1). It is known that the higher the phosphorus content lower the possibility of colonization, consequently the mycorrhizal colonization tends to be low (SMITH; READ, 2008). In conditions of low levels of phosphorus, the occurrence of mycorrhizal association provides better use of phosphate fertilizers and benefits in obtaining nutrients (JOBIM, 2015). Thus, temperature, $\mathrm{pH}$ and phosphorus levels directly influenced the infection capacity of the AMF used, and the plants inoculated with $A$. morrowiae were the most impaired, where colonization of the plants was stressful, increasing the TSS/TTA ratio, resulting in flavored fruits more acceptable by the consumer market.

Studies that investigate the conservation strategy so that biological resources can be approved in some way to increase the production or quality of natural products, from a perspective of sustainable development (JOBIM; OLIVEIRA; GOTO, 2016) should be incentives, such as the applicability of AMF.

\section{CONCLUSIONS}

The inoculation of AMF does not alter the production of strawberry fruits.

In addition, we verified that when the plants are inoculated with $A$. morrowiae there is improvement in the taste of the fruits of the Camarosa cultivar. Studies that seek to develop biotechnological tools to improve the production and quality of fruits, besides potentiating the use of a biological resource, as is the case of arbuscular mycorrhizal fungi deserve to be highlighted and further investigations.

\section{ACKNOWLEDGEMENTS}

To the Programa de Suporte à PósGraduação de Instituições Comunitárias de Ensino 
Particulares (PROSUC) of the Coordenação de Aperfeiçoamento de Pessoal de Nível Superior (CAPES) and to the Universidade de Passo Fundo (UPF). To the company Bioagro Comercial Agropecuária Ltda., for the supply of the strawberry mother plants (Camarosa cultivar) used in this work. We inform that this study was financied in part by the Coordenação de Aperfeiçoamento de Pessoal de
Nível Superior - Brazil (CAPES) - Finance Code 001. In addition, we declare that the AMF used in this study are regulated by the Sistema Nacional de Gestão do Patrimônio Genético e do Conhecimento Tradicional Associado (SisGen) of the Ministry of the Environment, Brazil, according to the registration number A198F50.

RESUMO: A necessidade de desenvolver e usar ferramentas biotecnológicas para melhorar o manejo e as técnicas nutricionais no cultivo do morangueiro está aumentando. Com base nisso, o objetivo desse estudo foi testar se a inoculação micorrízica altera o desempenho agronômico e qualitativo de frutos de morangueiro. As mudas de morangueiro usadas foram da cultivar Camarosa. O estudo foi realizado em estufa agrícola, no Setor de Horticultura da Faculdade de Agronomia e Medicina Veterinária (FAMV) da UPF, na cidade de Passo Fundo, Rio Grande do Sul (RS), Brasil. O experimento foi desenvolvido e mantido de junho a dezembro de 2015. Os tratamentos consistiram em cinco inóculos: $\mathrm{T} 1=$ sem inóculo (controle); T2 = Acaulospora morrowiae; $\mathrm{T} 3$ = Rhizophagus clarus; $\mathrm{T} 4=$ comunidade micorrízica; $\mathrm{T} 5=$ Claroideoglomus etunicatum. $\mathrm{O}$ delineamento experimental foi em blocos casualizados, com quatro repetições. Cada parcela consistiu de um saco contendo 6 plantas espaçadas de $0.15 \mathrm{mx} 0.15 \mathrm{~m}$. Na cova de plantio das plantas, foi aplicado, com auxílio de seringa e água, cerca de 70 propágulos infectivos dos inóculos testados. Durante a condução do experimento, a temperatura e a radiação fotossinteticamente ativa (PAR) foram monitoradas no ambiente de cultivo. Foi avaliado o desempenho agronômico e qualitativo dos frutos e a porcentagem de colonização micorrízica das raízes das plantas. Os dados foram submetidos à análise de variância e as diferenças entre médias foram comparadas pelo teste de Tukey, a 5\% de erro de probabilidade de erro. A cultivar Camarosa produziu mais frutos em outubro. Em setembro, no mês anterior ao de melhor desempenho agronômico, a temperatura média foi de $17.7^{\circ} \mathrm{C}$. A PAR média registrada no ambiente de cultivo foi baixa em relação às necessidades da cultura durante todo o período de cultivo. Frutos produzidos por plantas inoculadas com $A$. morrowiae apresentaram maiores valores da relação SST/ATT em setembro e outubro. A porcentagem de colonização micorrízica variou de $26.2 \%$ para $A$. morrowiae a $46.2 \%$ para $R$. clarus. A inoculação de fungos micorrízicos arbusculares não altera a produção de frutos de morangueiro. No entanto, quando as plantas são inoculadas $\operatorname{com}$ A. morrowiae, há uma melhora no sabor dos frutos.

PALAVRAS-CHAVE: Fragaria X ananassa Duch. Fungos micorrízicos arbusculares. Sólidos solúveis totais. Acidez total titulável.

\section{REFERENCES}

AHANGER, M. A.; ABEER, H.; ABD-ALLAH, E. F.; AHMAD, P. Arbuscular mycorrhiza in crop improvement under environmental stress. In: AHMAD, P.; RASOOL, S. (Eds). Emerging technologies and management of crop stress tolerance: a sustainable approach. USA: Academic Press, 2014. p. 69-95. https://doi.org/10.1016/C2013-0-19048-4

CECATTO, A. P.; MARTÍNEZ, F.; CALVETE, E. O.; MARTINEZ, J.; PALENCIA, P. Mycorrhizal inoculation affects the phytochemical content in strawberry fruits. Acta Scientiarum. Agronomy, v. 38, p. 227-237, 2016. https://doi.org/10.4025/actasciagron.v38i2.27932

CHIOMENTO, J. L. T.; COSTA, R. C.; DE NARDI, F. S.; TRENTIN, N. S.; NIENOW, A. A.; CALVETE, E. $\mathrm{O}$. Arbuscular mycorrhizal fungi communities improve the phytochemical quality of strawberry. The Journal of Horticultural Science and Biotechnology, v. 94, n. 5, p. 653-663, 2019.

https://doi.org/10.1080/14620316.2019.1599699 
CORBESIER, L.; COUPLAND, G. Photoperiodic flowering of Arabidopsis: integrating genetic and physiological approaches to characterization of the floral stimulus. Plant, Cell \& Environment, v. 28, p. 5466, 2005. https://doi.org/10.1111/j.1365-3040.2005.01283.x

COSTA, R. C.; CALVETE, E. O.; MENDONÇA, H. F. C.; DE COSTA, L. A. Phenology and leaf accumulation in vernalized and non-vernalized strawberry seedlings in neutral-days. Acta Scientiarum. Agronomy, v. 36, p. 57-62, 2014. https://doi.org/10.4025/actasciagron.v36i1.17285

DEPARDIEU, C.; PRÉMONT, V.; BOILY, C.; CARON, J. Sawdust and bark-based substrates for soilless strawberry production: irrigation and electrical conductivity management. PLoS One, v. 11, p. 1-20, 2016. https://doi.org/10.1371/journal.pone.0154104

ELBON, A.; WHALEN, J. Phosphorus supply to vegetable crops from arbuscular mycorrhizal fungi: a review. Biological Agriculture \& Horticulture, v. 31, p. 73-90, 2015. https://doi.org/10.1080/01448765.2014.966147

ELSER, J. J. Phosphorus: a limiting nutrient for humanity? Current Opinion in Biotechnology, v, 6, p. 833838, 2012. https://doi.org/10.1016/j.copbio.2012.03.001

FAGHERAZZI, A. F.; GRIMALDI, F.; KRETZSCHMAR, A. A.; MOLINA, A. R.; GONÇALVES, M. A.; ANTUNES, L. E. C.; BARUZZI, G.; RUFATO, L. Strawberry production progress in Brazil. Acta Horticulturae, v. 1156, p. 937-940, 2017. https://doi.org/10.17660/ActaHortic.2017.1156.138

FRANCIS, F. Foodcolourants: anthocyanins. Critical Reviews in Food Science and Nutrition, v. 28, p. $273-$ 314, 1989. https://doi.org/10.1080/10408398909527503

GÓMEZ-BELLOT, M. J.; NORTES, P. A.; ORTUÑO, M. F.; ROMERO, C.; FERNÁNDEZ-GARCÍA, N.; SÁNCHEZ-BLANCOA, M. J. Influence of arbuscular mycorrhizal fungi and treated wastewater on water relations and leaf structure alterations of Viburnum tinus L. plants during both saline and recovery periods. Journal of Plant Physiology, v. 188, p. 96-105, 2015. https://doi.org/10.1016/j.jplph.2015.09.007

GUTJAHR, C. Phytohormone signaling in arbuscular mycorhiza development. Current Opinion in Plant Biology, v. 20, p. 26-34, 2014. https://doi.org/10.1016/j.pbi.2014.04.003

HARTZ, T. K.; HOCHMUTH, G. J. Fertility management of drip-irrigated vegetables. HortTechnology, v. 6, p. 168-172, 1996. https://doi.org/10.21273/HORTTECH.6.3.168

HEIDE, O. M.; STAVANG, J. A.; SØNSTEBY, A. Physiology and genetics of flowering in cultivated and wild strawberries. The Journal of Horticultural Science and Biotechnology, v. 88, p. 1-18, 2013.

https://doi.org/10.1080/14620316.2013.11512930

IAL. Instituto Adolfo Lutz. Métodos físico-químicos para análise de alimentos. ZENEBON, O.; PASCUET, N. S.; TIGLEA, P. (Org.). 4. ed. São Paulo: Instituto Adolfo Lutz, 2008. 1020 p. Primeira edição digital.

JOBIM, K. Fungos micorrízicos arbusculares (Glomeromycota) em diferentes níveis de profundidade em fragmentos florestais. Natal: Universidade Federal do Rio Grande do Norte, 2015. Dissertação de Mestrado.

JOBIM, K., OLIVEIRA, B. I. S., GOTO, B. T. Checklist of the Glomeromycota in the Brazilian savanna. Micotaxon, v. 131, p. 1-13, 2016.

JUNG, J. H.; JU, Y.; SEO, P. J.; LEE, J. H.; PARK, C. M. The SOC1-SPL module integrates photoperiod and gibberellic acid signals to control flowering time in Arabidopsis. The Plant Journal, v. 69, p. 577-588, 2012. https://doi.org/10.1111/j.1365-313X.2011.04813.x

KIMURA, M. Vegetative growth and reproductive growth. In: Encyclopedia in vegetable crops horticulture: strawberry. Tokyo: Nobunkyo, 2008. 692 p. 
KIRSCHBAUM, D. S. Temperature and growth regulator effects on growth and development of strawberry (Fragaria x ananassa Duch.). Flórida: University of Florida, 1998. Tese de Doutorado.

MARTINEZ, F.; WEILAND, C.; PALENCIA, P. The influence of arbuscular mycorrhizal fungi inoculation method on growth of strawberry plants in a soilless growing system. Acta Horticulturae, v. 1013, p. 487-492, 2013. https://doi.org/10.17660/ActaHortic.2013.1013.60

MORCILLO, R. J. L.; NAVARRETEA, M. I. T.; BOTEA, J. A. O.; MONGUIOB, S. P.; GARCÍAGARRIDOA, J. M. Suppression of allene oxide synthase 3 in potato increases degree of arbuscular mycorrhizal fungal colonization. Journal of Plant Physiology, v. 190, p. 15-25, 2016.

https://doi.org/10.1016/j.jplph.2015.11.003

NAVARRO, J. M.; PEREZ-TORNERO, O.; MORTE, A. Alleviation of salt stress in citrus seedlings inoculated with arbuscular mycorrhizal fungi depends on the rootstock salt tolerance. Journal of Plant Physiology, v. 171, p. 76-85, 2014. https://doi.org/10.1016/j.jplph.2013.06.006

OPSTAD, N.; SØNSTEBY, A.; MYRHEIM, U.; HEIDE, O. M. Seasonal timing of floral initiation in strawberry: effects of cultivar and geographic location. Scientia Horticulturae, v. 129, p. 127-134, 2011. https://doi.org/10.1016/j.scienta.2011.03.022

PALENCIA, P.; MARTÍNEZ, F.; MEDINA, J. J.; MEDINA, J. L. Strawberry yield efficiency and its correlation with temperature and solar radiation. Horticultura Brasileira, v. 31, p. 93-99, 2013. https://doi.org/10.1590/S0102-05362013000100015

PASZT, L. S.; MALUSÁ, E.; SUMOROK, B.; CANFORA, L.; DERKOWSKA, E.; GŁUSZEK, S. The influence of bioproducts on mycorrhizal occurrence and diversity in the rhizosphere of strawberry plants under controlled conditions. Advances in Microbial Physiology, v. 5, p. 40-53, 2015. http://dx.doi.org/10.4236/aim.2015.51005

PERKINS-VEAZIE, P.; COLLINS, J. K. Strawberry fruit quality and its maintenance in postharvest environments. Advances in Strawberry Research, v. 14, p. 1-8, 1995.

PHILLIPS, J. M.; HAYMAN, D. S. Improved procedures for clearing roots and staining parasitic and vesiculararbuscular mycorrhizal fungi for rapid assessment of infection. Transactions of the British Mycological Society, v. 55, p. 158-160, 1970. https://doi.org/10.1016/S0007-1536(70)80110-3

SHARMA, M. P.; ADHOLEYA, A. Influence of arbuscular mycorrhizal fungi and phosphorus fertilization on the post-vitro growth and yield of micropropagated strawberry in an alfisol. Canadian Journal of Botany, v. 82, p. 322-328, 2004. https://doi.org/10.1139/b04-007

SILVEIRA, A. P. D. Ecologia de fungos micorrízicos arbusculares. In: MELO, I. S.; AZEVEDO, J. L. (Eds.). Ecologia microbioana. Jaguariúna: Embrapa-CPNMA, 1998. p. 61-83.

SMITH, S. E.; READ., D. J. Mycorrhizal symbiosis. 3. ed. Califórnia: Academic Press, 2008. 605 p.

SØNSTEBY, A.; HEIDE, O. M. Temperature responses, flowering and fruit yield of the June-bearing strawberry cultivars Florence, Frida and Korona. Scientia Horticulturae, v. 119, p. 49-54, 2008.

https://doi.org/10.1016/j.scienta.2008.07.005

TAIZ, L.; ZEIGER, E.; MOLLER, I. M.; MURPHY, A. Fisiologia e desenvolvimento vegetal. 6. ed. Porto Alegre: Artmed, 2017. 888 p.

TORUN, A. A.; KACAR, Y. A.; BIÇEN, B.; ERDEM, N.; SERÇE, S. In vitro screening of octoploid Fragaria chiloensis and Fragaria virginiana genotypes against iron deficiency. Turkish Journal of Agriculture and Forestry, v. 38, p. 169-174, 2014. https://doi.org/10.3906/tar-1305-83 
TROUVELOT, A.; KOUGH, J. L.; GIANINAZZI-PEARSON, V. Mesure du taux de mycorhization VA d'un systeme radiculaire: recherche de methodes d'estimation ayant une signification fonctionelle. In: GIANINAZZI-PEARSON, V.; GIANINAZZI, S. (Eds.). Physiological and genetic aspects of mycorrhizae. Paris: INRA Press, 1986. p. 217-221.

TRUFEN, S. F. B. Aspectos ecológicos de fungos micorrízicos vesículo-arbusculares da mata tropical úmida da Ilha do Cardoso, SP. Brasil. Acta Botanica Brasilica, v. 4, p. 31-45, 1990. https://doi.org/10.1590/S010233061990000200003

WANG, S. Y.; CAMP, M. J. Temperatures after bloom affect plant growth and fruit quality of strawberry. Scientia Horticulturae, v. 85, p. 183-199, 2000. https://doi.org/10.1016/S0304-4238(99)00143-0

WILLIS, A.; RODRIGUES, B.; HARRIS, P. J. C. The ecology of arbuscular mycorrhizal fungi. Critical Reviews in Plant Sciences, v. 32, p. 1-20, 2013. https://doi.org/10.1080/07352689.2012.683375

XU, L.; ZHANG, T. Influence of light intensity on extracted colour feature of different mature strawberry. New Zealand Journal of Agricultural Research, v. 250, p. 559-565, 2007.

https://doi.org/10.1080/00288230709510323 